Apidologie, 1985, 16 (3), 275-290

\title{
A PRELIMINARY QUALITATIVE AND QUANTITATIVE STUDY OF THE MICROSCOPIC STRUCTURE OF THE DORSAL FAT BODY IN ADULT HONEYBEES (APIS MELLIFERA L.), INCLUDING A TECHNIQUE FOR THE PREPARATION OF WHOLE SECTIONS
}

Hilde RAES, Frans JACOBS and Edith MASTYN

Laboratory of Zoophysiology, State University of Gent

K.L. Ledeganckstraat 35, B-9000 Gent, Belgitum

SUMMARY

The fat body of adult honeybees is being studied both qualitatively and quantitatively in search of parameters for their physiological condition.

A detailed description of a histological technique for the preparation of overall sections in the plane of this sheatlike tissue is presented. The cellular organisation of a complete segmental fat body can now be studied on a few serial sections. New cytological data on the 3rd, 4th, 5th and 6 th tergite fat body are presented.

Oenocytes are not randomly distributed among the fat cells; their occurrence is lowest near the heart and increases laterally. Whereas this is a general trend within the different tergites, it is most pronounced in the 3rd tergite where an area close to the heart is free of oenocytes.

The relative protein granule concentration in the fat cells has been studied in young and old autumn bees. The granules appear synchronously and with the same relative concentration in the four segments studied. Within the $3 \mathrm{rd}$ segment, the granule distribution is even in young, but not in older bees where we found significant concentration differences between seven sample areas. The granule depletion rate is apparently higher where the fat cells are lying close to other tissue.

The present results are a necessary preliminary to accurate sampling which is a prerequisite for further quantitative light and electron microscopy analysis.

\section{INTRODUCTION}

The insect fat body (F.B.) is not only an important storage organ, but also a principal site for intermediary metabolism (KILBY, 1965), and a target organ for all of the major types of insect hormones (KEELEY, 1978). 
Probably due to technical difficulties, the adult fat body of the honeybee has been studied only very sparsely (Koehler, 1921; Kramer, 1962; BOEHM, 1964).

The general appearance of this organ in shortliving summerbees is thoroughly different from that in longliving winterbees (Lotmar, 1939). Maurizio (1961) states that the developmental situation of the adult F.B. is a prime parameter for the physiological condition and for the life expectancy of the insect. The development of the F.B. into a thick, white organ, filled with protein granules during fall, which enables the animal to survive through the winter, is determined directly by its protein intake (MaUrizıo, 1961).

In the studies of Lotmar (1939) and Maurizio $(1954 ; 1961)$ the development of the F.B. was evaluated with a score method based on its general external appearance. Whereas this method is certainly valuable to get a gross estimate of the developmental situation of a honeybee colony, it lacks objectivity and gives no data about the cytology of the organ.

Most histological work has been done on sections through the entire abdomen. As the abdominal fat body of the honeybee consists of a single cell layer lining the abdominal wall, very few fat body cells per section can be studied this way. This makes systematic investigation extremely time consuming, and may lead to wrong conclusions if the tissue is not homogeneous.

Our aim is to study the development of the adult F.B. in different age groups throughout the year qualitatively and quantitatively as a parameter for the physiological condition of the honeybee. We believe that a thorough knowledge of the F.B. from bees in their natural situation will facilitate the interpretation of material from experimental and pathological situations.

As the first of a series of papers on the microscopic morphology of the dorsal part of the fat body (D.F.B.) of the adult honeybee, this paper contains :

a) a preparation and embedding technique which makes it possible to study the cells of a segmental fat body sheet on a few histological sections;

b) a preliminary description and quantitative analysis of tissue sections prepared by this method.

\section{MATERIAL AND METHODS}

Bees less than $24 \mathrm{~h}$ old, emerged in the incubator at $30^{\circ} \mathrm{C}$ from sealed brood, were color marked on the thorax and joined to their own colony. Thus animals of any desired age could be recaptured when needed. The results described in this paper are from autumnbees (Merz et al., 1978) emerged between the 20th and 30th of August. Their life expectancy is intermediate between that of summerbees and winterbees. 


\section{Dissection and preparation of the tissue}

After the removal of the digestive tract, the isolated abdomen is dissected in Wyatt saline. The tergites and sternites are gently torn apart. Airsacs, tracheae and the heart are carefully removed. The tergites are then carefully separated from one another and the segmental fat bodies cut free with the point of a fine injection needle. Whereas the tissue looks very delicate, the composing cells are rather coherent. With some practice each sheet can be removed in its entirety.

The following procedures were developed based on the knowledge that fat body tissue sticks very easily to the surface of a cover-slip.

With a pasteur pipette, the tissue is transferred from the saline to a cover-slip, and with the help of fine tweezers, the sheet is spread out as completely as possible. The Wyatt solution is carefully removed with a strip of blotting paper. It is important that a thin layer of the liquid remains between the tissue and the glass surface to enable complete surrounding by the fixative during the next step. The tissue is then immediately covered with a fast penetrating histological fixative which in turn is carefully removed as completely as possible. The cover-slip, with the tissue now firmly adhering to its surface is then submerged in a petri dish filled with the fixative. We found that Helly's fixative (GANTER and Jolles, 1969) produces very good results ; Carnoy, Bouin, Bouin-Hollande or formalin are less suited for this method. The cover-slip with the tissue remains on the bottom of the petri disk while the successive bathing fluide are changed in preparation to paraffin embedding.

\section{Embedding and sectioning of the tissue}

Special brass accessories were conceived to enable embedding in such a way that the paraffin block can be cut exactly in the plane of the tissue without prior trimming. They consist of : a casting mould (Fig. 1); an object disc (Fig. 2) and a ring (Fig. 3). The dimensions of these accessories and their mutual proportions are important for the method to be successful.

The different steps involved in embedding the fat body tissue are schematically shown in Fig. 4 and will be briefly discussed.

A herating plate is set ready at about $75^{\circ} \mathrm{C}$, covered by a sheet of blotting paper and as many microscope slides as there are fat bodies to be embedded. On each slide a drop of xylol is pipetted. A cover-slip with tissue is picked from the last paraffine bath and blotted carefully against the warm blotting paper to remove most of the adhering paraffine. With the tissue at the topside the cover-slip is placed unto the xylol drop (step 1 and 2), which prevents it from sticking to the microscope slide once the paraffin is hardened. A casting mould is placed around the tissue, with the base of the parallelogram in parallel to the caudal side of the fat body, and filled with melted paraffine (step 3 and 4 ). The whole is then removed from the heating plate to cool (step 5).

The slide, the cover-slip and the casting mould are successively removed from the paraffin block, leaving the tissue embedded in the plane underside of the block (step 6).

An object disc is kept on the heating plate; the paraffin block is put with the plane side on a microscope slide, surrounded by the ring (step 7). The prewarmed object disc is then pressed firmly against the paraffine and the ring (step 8), which keeps the disc level with the tissue.

When the ring is removed, the object disc can be clamped in the tissue carrier of a sliding microtome. The tissue carrier should be leveled on beforehand with the help of a waterlevel; the object disc should rest on the sides of the tissue carrier. $5 \mu \mathrm{m}$ serial sections are made in the usual way.

\section{Estimation of the oenocyte distribution in the D.F.B.}

The oenocyte distribution was studied in autumnbees of 4 and 35 days old. For each of the four tergites studied, the number of oenocytes in seven rectangles of 278 by $425 \mu \mathrm{m}$, was counted (this is the surface covered by the photographic rectangle of a Leitz Orthomat photographic installation, magnification $12.5 \times 40$ ). 


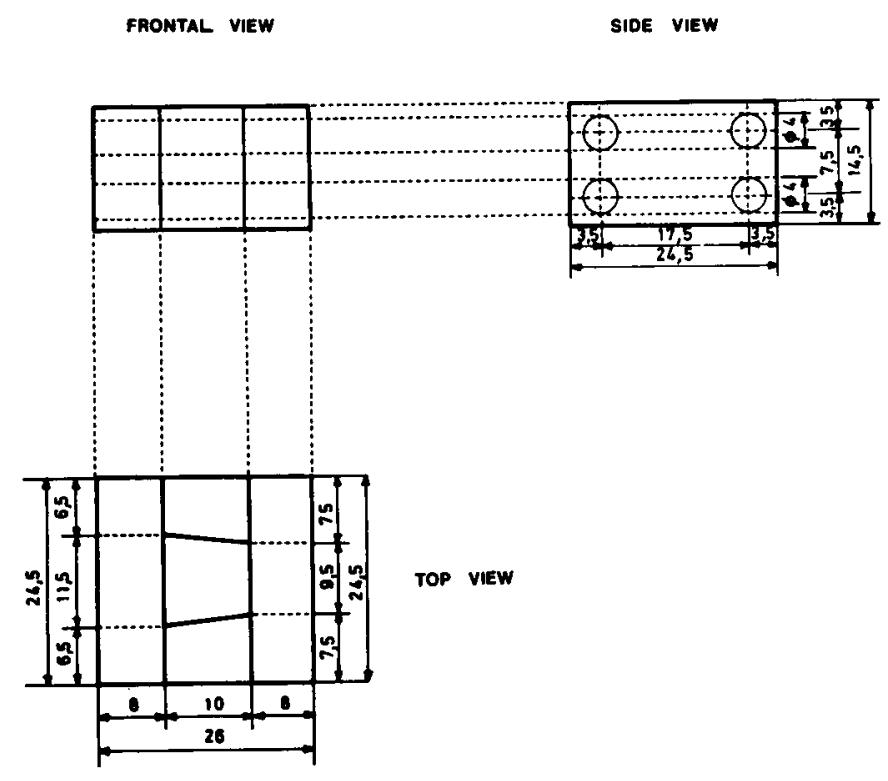

1
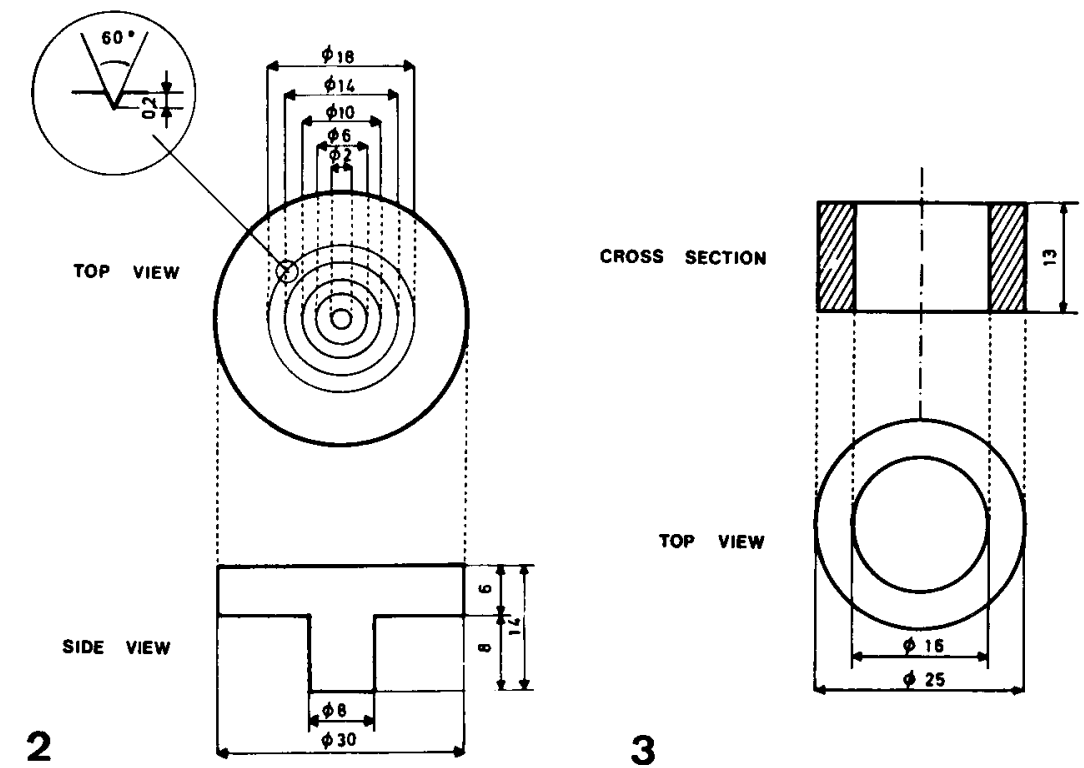

3

FIG. 1-3. - Plans of the brass accessories for plane embedding of the tissue : casting mould (Fig. 1), object disc (Fig. 2) and ring (Fig. 3) 


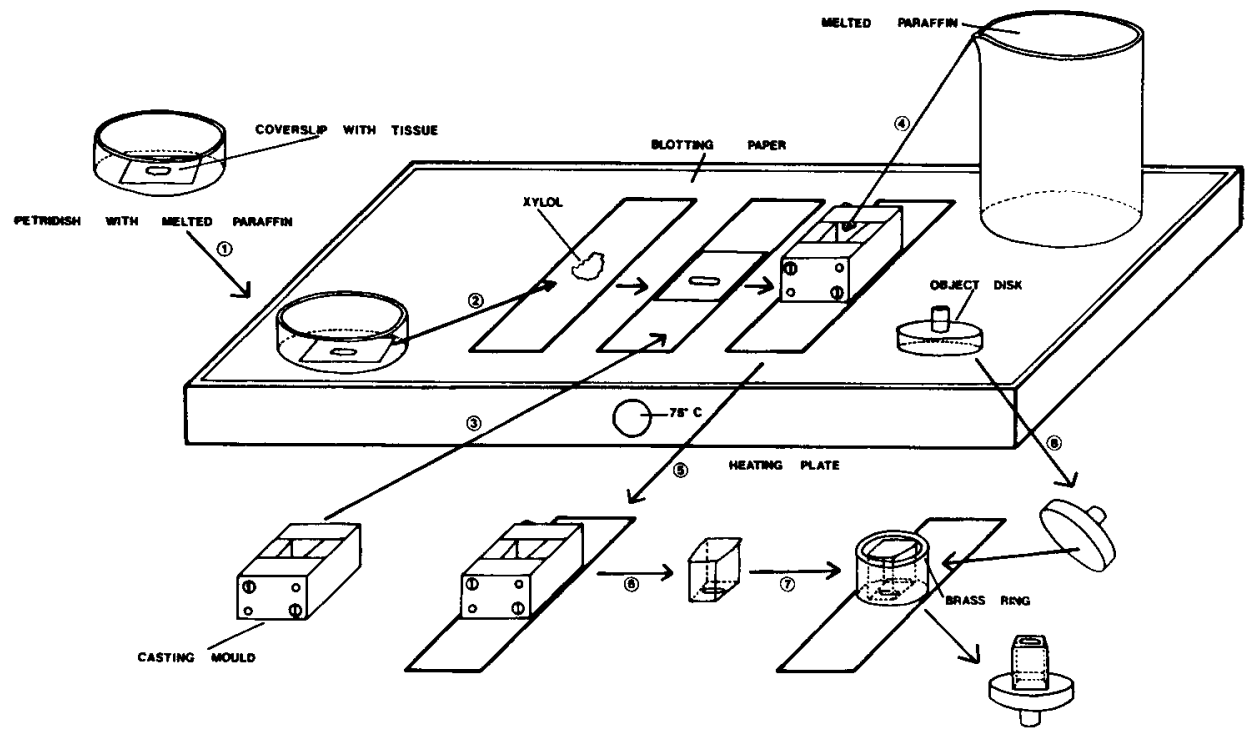

Fis, 4. - Schematic representation of the different steps, outlined in the text, involved in plane embedding of the fat body tissue

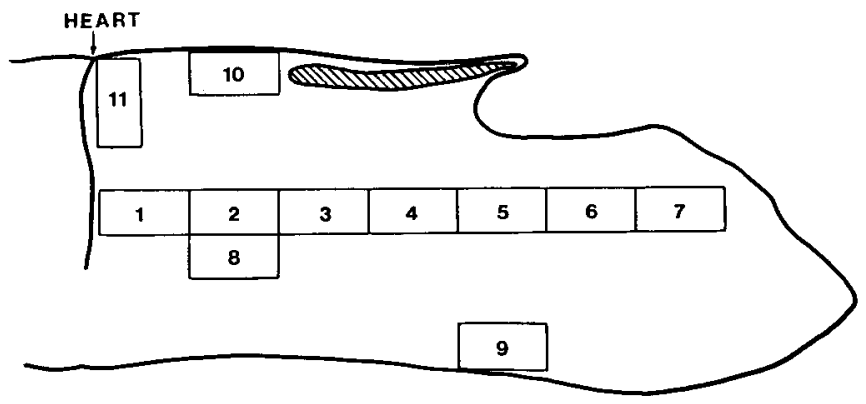

FIG. 5. - Schematic representation of half a segmental dorsal fat body showing the numbered sample areas

The sample areas are the rectangles numbered 1 to 7 , on Fig. 5. Ten animals were sampled for each of the two age groups. The countings were always done on the middle one of the serial sections.

\section{Estimation of the protein granule concentration}

We intended to compare the relative granule density :

1) between well defined sample areas of different tergite fat bodies and

2) within the fat body of the 3rd tergite.

We sampled on each of the four tergites in areas 2 and 8 (Fig. 5) and within the 3rd tergite in areas $2,9,10,11$ and 6 . 
Micrographs were made of $5 \mu \mathrm{m}$ sections at a magnification of $12.5 \times 40$, following the Azan method which gives a very good contrast for the protein granules. The micrographs were made with an Orthomat photographic installation on a Leitz Dialux microscope. The negative micrographs were projected from a fixed distance on a type D 64 lattice (WEIBEL, 1979) with $\mathrm{d}=2 \mathrm{~cm}$ totalling 1024 points. The relative granule concentration can be calculated, expressed as a percentage of total cytoplasmic area.

\section{RESULTS}

General description of the dorsal fat body of the adult honeybee

The sheetlike adult fat body covers practically the whole abdominal wall. It is segmentally arranged. Per tergite the unicellular sheet is attached to the epidermis at the posterior end. At the anterior edge, the connection is much looser. In the middle, the dorsal fat body (D.F.B.) is kept into place by the heart and laterally by the longitudinal muscles. Firmly attached to the heart is the dorsal diafragm with its muscles and pericardial cells.

The 2nd abdominal segment contains only a very tiny piece of fat body. In the 3rd segment, the D.F.B. is in loose connection with the heart and can therefore be dissected as one piece. In the succeeding segments, this connection is gradually more firm until the heart divides the fat body into two lateral parts. The very small pieces of fat body tissue in the 2 nd and 7 th segment were omitted from this study.

A survey micrograph of the 3rd D.F.B. prepared as described above is shown in Fig. 6 ; it shows part of an overall picture of a whole section through the 3rd segment D.F.B. in the plane of this sheetlike organ.

On our sections, the different tissues mentioned above may be seen occasionally.

The main cell types in the adult fat body of the honey bee are the fat cells and the oenocytes (Fig. 7). Between the fat body cells we always found many tracheal endcells (Fig. 8).

Haemocytes constitute another cell type that is regularly found in close contact with the fat body cells. Their cytoplasm is often filled with granules and they seem transport materials to or from the fat body cells (Fig. 8).

Near the anterior border of the third segment D.F.B. left and right, along the tracheal trunks a small piece of yellowish tissue can be found. This structure exists in young summerbees and in winterbees throughout their life. Due to its very loose and unorderly appearance it was at first mistakenly interpreted as an accidental accumulation of haemocytes (Fig. 9). 


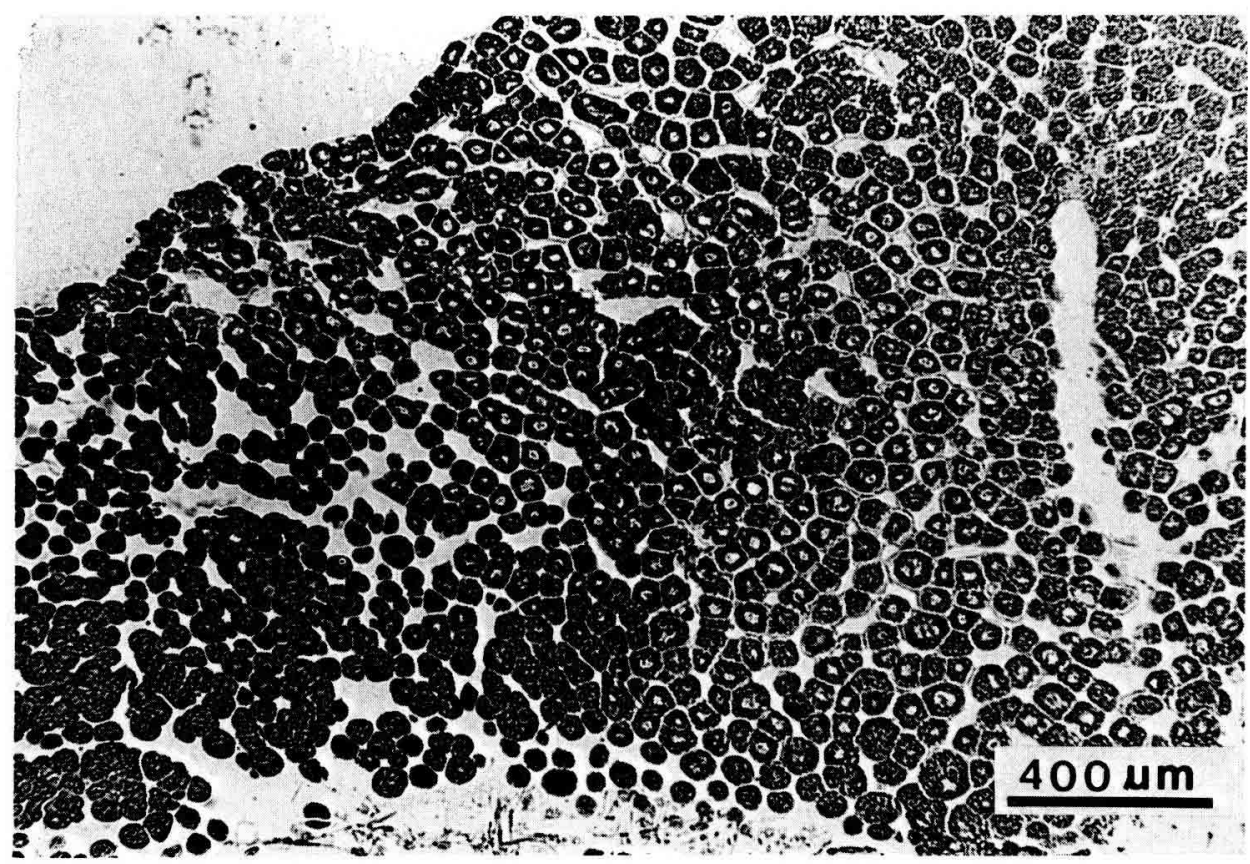

FIG. 6. - Survey micrograph showing part of an overall picture of a whole sectiont through the 3rd tergite fat body

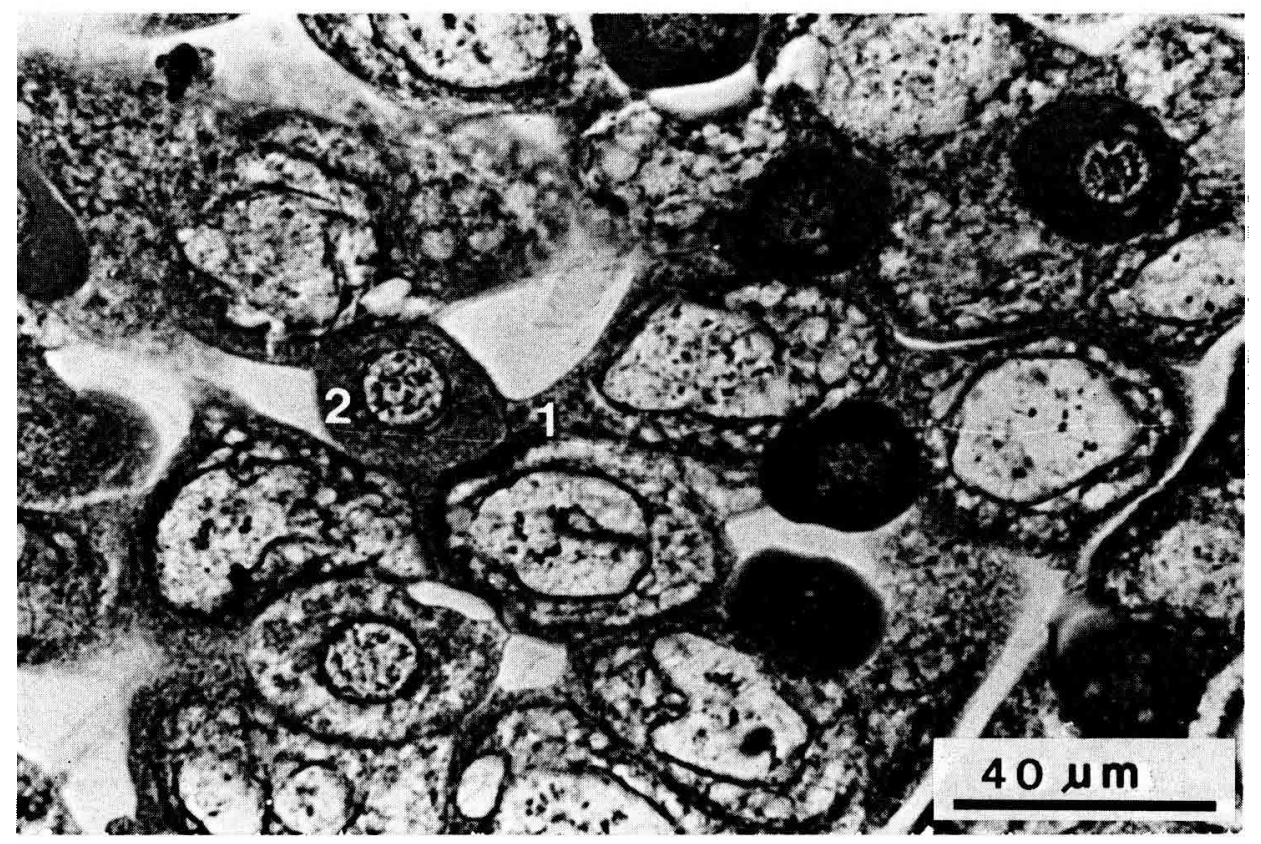

FIG. 7. - The main cell types in the fat body: fat cells (1) and oenocytes (2) 


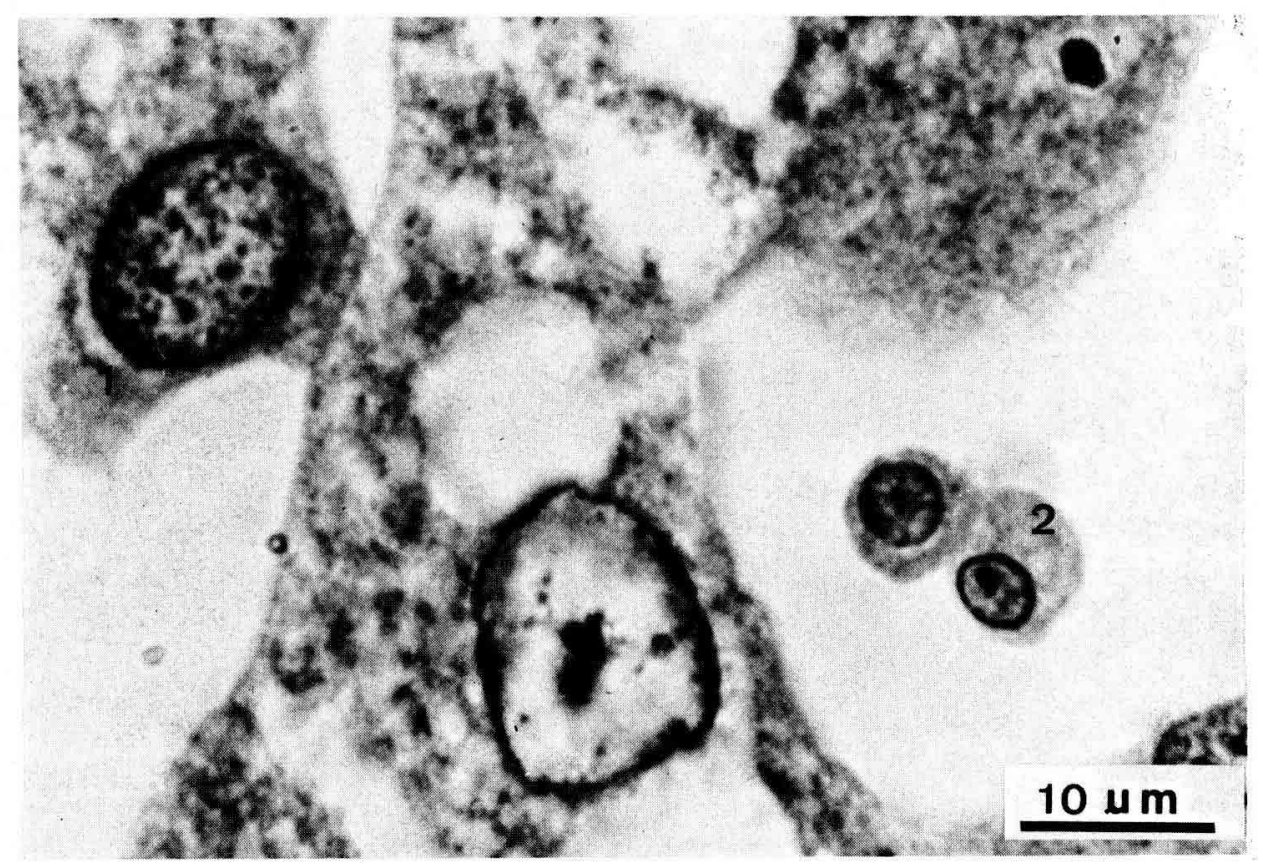

FrG. 8. - Tracheal end cell (1) and haemocytes (2) lying between the fat cells

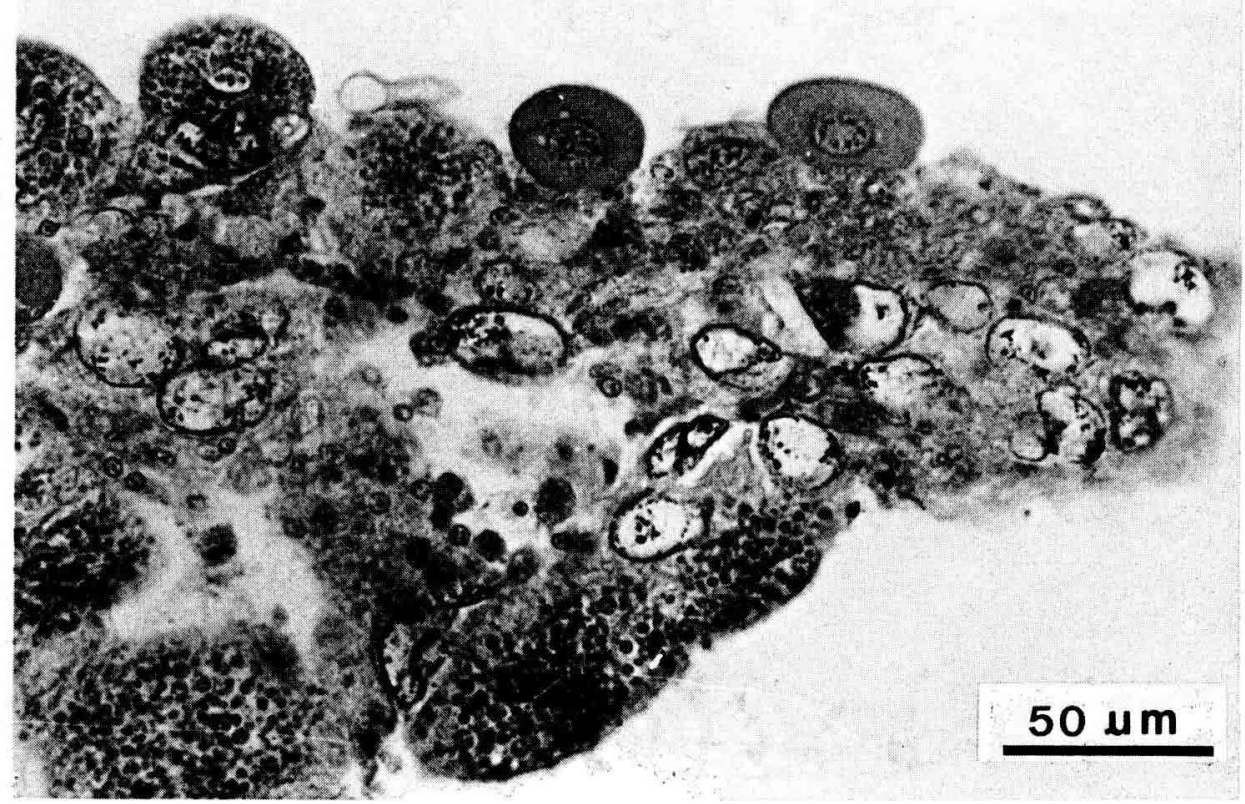

FIG. 9. - Part of unknown piece of tissue found at the anterior border of the 3rd tergite fat body 
Distribution of the oenocytes in the D.F.B. of the 3rd, 4th, 5th and 6th segment

The adult oenocytes originate from the abdominal epidermis (SchNelle, 1923). According to Kramli (1962), there is no clustering of the adult oenocytes near the tracheal trunks. As contrasted with larval oenocytes, they are randomly seattered between the fat cells.

Our observations made it clear that, at least in the 3rd segment D.F.B., the oenocyte distribution is not random. This fact may have practical as well as functional implications and therefore was more thouroughly investigated.

It was also suggested by Kramer (1962) that, throughout the life of the adult honeybee, some oenocytes become active and thereafter degenerate, while others remain undeveloped and serve as reserve generation. If this assumption is correct, there should be a decrease in the number of oenocytes when the insect grows older - adult oenocytes are non dividing cells - We therefore compared the oenocyte distribution and density in bees of respectively 4- and 35-day old.

The results, presented in figure 10 , show that the oenocyte distribution is not the same in the different tergite fat bodies. There is always a gradient from the heart, where the concentration is the lowest towards the lateral part of the fat body near the tracheal trunk. In the 3rd segment D.F.B., an area near the heart is completely free of oenocytes.

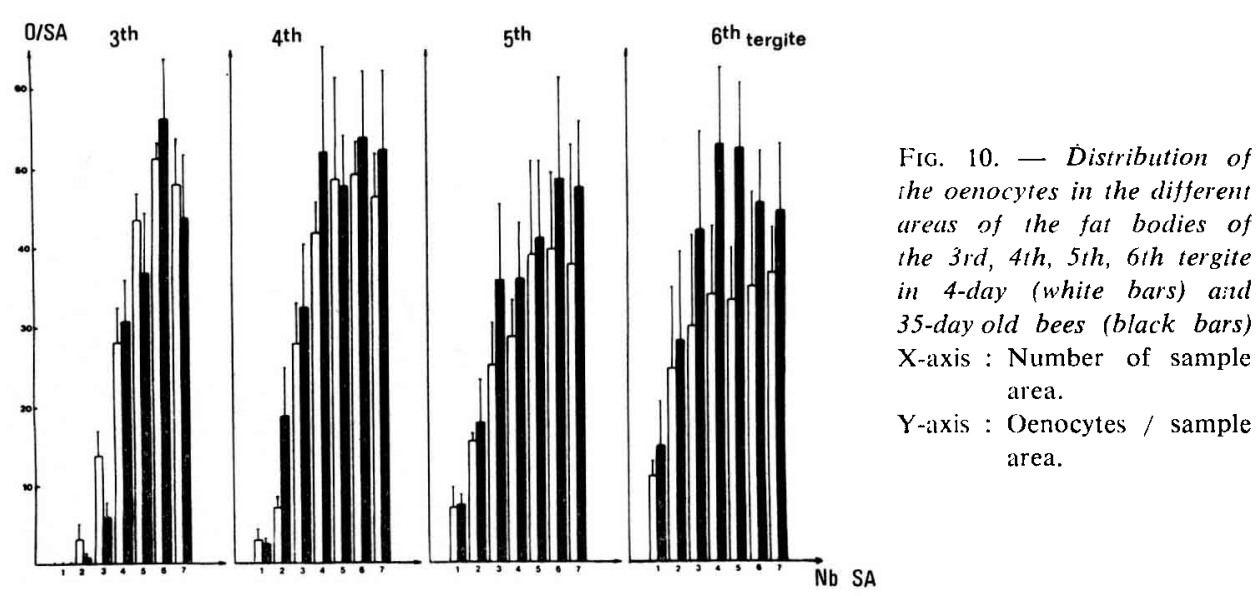

There is clearly no decrease in the number of oenocytes in old bses. In the 5th and 6th segment, the number of oenocytes per sample area is even significantly higher in 35-day old bees than in 4-day old bees. 
Relative protein granule density in the D.F.B. of the $3 r d, 4 t h, 5 t h$ and 6 th segment

The method for protein granule quantification is too time consuming to permit random sampling, therefore, sampling must be done as efficiently as possible.

TABL. 1. - Relative protein granule density

in fat cells of the different segmental D.F.B. of 12-day old autumn bees

\begin{tabular}{l|c}
\hline $\mathrm{n}=10$ & $\begin{array}{c}\text { Relative protein granule concentration } \\
\mathrm{x} \pm \mathrm{S}\end{array}$ \\
\hline 3rd tergite & $57.95 \% \pm 7.25$ \\
4th tergite & $52.52 \% \pm 9.82$ \\
5th tergite & $55.22 \% \pm 6.57$ \\
6th tergite & $58.33 \% \pm 7.76$ \\
\hline
\end{tabular}

We first wanted to know if there exists systematic differences between the four tergites. The results (Table 1) are given as the percentages of protein granule area to total cytoplasm area. They show that, if the sampling is done in corresponding areas, the protein granule density in the respective segments is not significantly different.

Because in 12-day old autumnbees the granule concentration is already relatively high we also looked at 4 -day old autumnbees. This group includes animals whose fatcells are still free of protein granules and others where the first granules are already apparent. If granule formation does not happen synchronously in the different segments, this should be conspicuous on these sections. We never found a different developmental situation in the D.F.B.'s of the same animal.

From these results we conclude that for granule quantification it is not necessary to make histological preparations of the different tergite fat bodies. Because the 3rd segment D.F.B. is the easiest for dissection and preparation and has a zone which is free of oenocytes, we selected this part of the D.F.B. for further investigation.

Distribution of the protein granules within the 3rd segment D.F.B.

From the observations of many sections, it appeared that the protein granule distribution within one segment D.F.B. does not remain homogeneous throughout adult life. We therefore sampled the 3rd segment D.F.B. in five well defined areas (Fig. 5) in 8- and 35-days old autumnbees to see if there are systematic differences between these sample areas. 
The results in table 2 are given as the percentages of protein granule area to total cytoplasm area. These percentages were submitted to an angular transformation in order to allow statistical analysis by a one way anovar (SoKaL \& ROHLF, 1969).

TABL. 2. - Relative protein granule density in five different sample areas in the 3rd tergite fat cells of 8-and 35-day old autumn bees

\begin{tabular}{c|c|c}
\hline \hline \multirow{2}{*}{$\begin{array}{c}\text { Sample area } \\
\mathrm{n}=10\end{array}$} & \multicolumn{2}{|c}{ Relative granule concentration $(\overline{\mathrm{x}} \pm \mathrm{S})$} \\
\cline { 2 - 3 } 10 & 8 days & 35 days \\
11 & $27.10 \% \pm 8.73$ & $32.34 \% \pm 10.20$ \\
2 & $32.52 \% \pm 7.14$ & $37.73 \% \pm 8.33$ \\
9 & $30.14 \% \pm 10.38$ & $46.98 \% \pm 10.09$ \\
6 & $28,70 \% \pm 9.30$ & $15.70 \% \pm 9.20$ \\
\hline
\end{tabular}

The large standard deviations show that there exist considerable variations between animals of the same age. In spite of this, there is a significant influence of the sample area on the relative granule concentration in 35-day old animals. The precise localisation of the sampling area within a segmental D.F.B. thus seems important for protein granule quantification.

\section{DISCUSSION}

Because it is a highly developed social insect, the physiological condition of the adult honeybee is very complex and variable; it depends on its social function, its physiological age and the season of the year. The fat body is a prime parameter for the physiological condition and the life expectancy of the insect (Maurizio, 1961 ; Rockstein, 1973 ; Haydak, 1957). Moreover, if we consider its central role in development and metabolism, it is imperative that we gain more knowledge about the fat body of the adult honeybee.

We think that part of the technical problems which hampered the histological study of this organ have been solved by our preparation method. However simple in its application, the successive steps described above must be followed very strictly in order to be successful.

It is clear however that the type of sections shown in Fig. 5, provides us with a lot of new information about the general organisation of this tissue. This 
is essential for accurate sampling in quantitative light microscopic and electron microscopic studies.

On our sections we frequently encountered pericardial tissue; we never found a noticable difference between pericardial and paracardial cells as described by SNODGRass (1956).

We always found many tracheal endcells between the fat body cells; to our knowledge they are not mentioned earlier in this context. As these cells are superficially resemblant to young oenocytes, they might correspond with the non developed oenocytes, which Kramer (1962) interpretes as probable spare osnocytes. According to SNODgrass (1956), the tracheae branch to fat cells but not to oenocytes. Our observations with phase contrast optics show clearly that tracheoles, derived from tracheal endcells end upon oenocytes as well as upon fat cells.

The structure found at the anteriour border of the 3rd segment D.F.B. and illustrated in figure 9 has, to our knowledge, not been mentioned before. The fact that it can always been found at the same spot in bees of a particular physiological condition shows that it must have a proper function. As it is always invaded by heamocytes of different types, its association with bloodcells seems obvious. We never found any mitotic cells in the tissue, which seems to exclude its possible role in hemopoiesis. This tissue is now being studied by electron microscopy and will be described in a later publication.

Contrary to Kramer (1962), we found that the oenocytes are not distributed at random between the fat cells (Fig. 10). Close to the heart there is an area in the D.F.G. which is devoid of oenocytes (3rd segment) or where they are scarce. From a practical point of view, the existence of the oenocyte free area in the fat body makes it possible to study the fat cell metabolism without interference of oenocytes.

In the literature, oenocytes are often considered to be secretory cells which produce necessary intermediates for the functioning of the fat cells (KRAMER, 1962 ; Pfeiffer, 1945 ; Maurizio, 1954). An exchange of products between both cell types is suggested by their mutual position, their histology and their ultrastructure. The existence of an oenocyte free area in the adult honeybee seems to indicate that it is possible for fat cells to function normally without close contact with an oenocyte.

Protein granule formation is a major feature of the fat body differentiation. Their occurence and concentration in the adult honeybee fat body is clearly correlated with the physiological condition of the animals (MAURIZIO, 1954). One of our objectives is the quantification of these granules throughout the adult life of honeybees in different seasons. It was therefore necessary to see 
first if the granule distribution is homogeneous in the different parts of the fat body. That this cannot be taken for granted is shown by the work of TYSELL and ButTerworTH (1977) : they demonstrated that in Drosophila larvae, the protein granule formation happens at a region-specific rate which results in a final distribution in an anterior-posterior gradient.

Our results show that granule formation in the different segmental D.F.B. starts synchronously and that the concentration rises equally in comparable areas of the different tergites.

Within the 3rd segment D.F.B., the granule distribution is homogeneous in young animal fat cells, but their gradual depletion does not occur uniformly throughout the tissue. Apparently depletion evolves faster in the areas where the fat body is in contact with other tissue i.e. : the heart, the posterior and anterior border and especially the longitudinal muscles (area 9). The contact with oenocytes has apparently no influence upon the protein granule concentration in the fat cells as there is no significant difference between area 2, devoid of oenocytes and area 6 where the oenocyte density is maximal.

The zonation of oenocytes and fat cell depletion was not mentioned earlier in the honeybee literature, probably because it becomes only conspicuous on whole sections. The results presented in this paper form a necessary preliminary for our further studies. The results of a comparative study of the cytological evolution of both fat cells and oenocytes in this type of sections in bees of different ages and seasons will be published shortly.

Received for publication in January 1985.

Accepted for publication in May 1985.

\author{
RÉSUMÉ \\ ETUDE PRELIMINAIRE QUALITATIVE ET QUANTITATIVE \\ DE LA STRUCTURE MICROSCOPIQUE DU CORPS GRAS DORSAL. \\ CHEZ L'ABEILLE ADULTE (APIS MELLIFICA L.) \\ ET TECHNIQUE DE PREPARATION DE SECTIONS TOTALES
}

\title{
Introduction
}

En dépit de son rôle primordial dans le métabolisme et en raison de difficultés techniques, le corps gras de l'abeille adulte n'a été que peu étudié. Notre but est d'étudier le développement du corps gras adulte dans divers groupes d'âge tout au long de l'année, sur le plan qualitatif et quantitatif, en tant que paramètre de la condition physiologique et de l'espérance de vie de l'insecte. 


\title{
Matériel et méthodes
}

On a mis au point une technique de préparation et d'inclusion pour étudier les cellules d'un corps gras segmentaire sur des coupes séries. Les couches du corps gras dorsal sont soigneusement disséquées à partir de l'abdomen éviscéré dans une solution de Wyatt et étalées sur un couvre-objet. Après avoir été fixé sur le couvre-objet, le tissu est déshydraté pour être inclus dans la paraffine.

A l'aide d'accessoires en cuivre spécialement conçus (Fig. 1, 2 et 3), on procède à l'inclusion du tissu suivant les diverses étapes présentées Fig. 4.

La distribution des oenocytes a été étudiée chez des abeilles d'automne âgées de 4 et 35 jours. Elles ont été comptées dans les régions 1 à 7 (Fig. 5) du corps gras des $3^{\mathrm{e}}, 4^{\mathrm{e}}, 5^{\mathrm{e}}$ et $6^{\mathrm{e}}$ tergite.

La densité relative des granules protéiniques dans les trophocytes a été déterminée par comptage de points sur des micrographies projetées sur une grille.

On a comparé la densité des granules du $3^{6}$ segment et des divers segments entre eux.

\section{Résultats}

Les Fig. 6, 7, 8 et 9 donnent une illustration générale du corps gras dorsal et des divers types de cellules rencontrées dans nos coupes histologiques.

La distribution des oenocytes au sein du corps gras varie d'un tergite à l'autre. Comme le montre la Fig. 10, il existe toujours un gradient du cour, où la concentration est la plus faible, vers les parties latérales du corps gras. Dans le $3^{e}$ segment, la région située près du cour est complètement dépourvue d'œnocytes.

La densité relative des granules dans les trophocytes des abeilles d'automne âgées de 12 jours est la même pour les 4 tergites étudiées (Tabl. 1) et la formation des granules a lieu en même temps dans les divers segments. La région échantillonnée à l'intérieur d'un segment influence de façon significative la concentration relative en granules chez les abeilles âgées de 35 jours, mais pas chez celles de 8 jours (Tabl. 2). Apparemment les granules s'épuisent plus vite dans les régions où le corps gras est en contact avec d'autres tissus.

Les résultats présents constituent un préliminaire indispensable à un échantillonnage précis, préalable à une analyse ultérieure en microscopie optique et électronique.

\section{ZUSAMMENFASSUNG}

\author{
VORLAUFIGE QUALITATIVE UND QUANTITATIVE UNTERSUCHUNG \\ DER MIKROSKOPISCHEN STRUKTUR DES DORSALEN FETTKÖRPERS \\ BEI ADULTEN HONIGBIENEN (APIS MELLIFERA L.) MIT DER BESCHREIBUNG \\ EINER TECHNIK ZUR PRÄPARATION VON ÜBERSICHTSSCHNITTEN
}

\section{Einleitung}

Trotz seiner zentralen Bedeutung für den Stoffwechsel wurde der Fettkörper der erwachsenen Biene bisher nur wenig untersucht, wahrscheinlich vor allem wegen technischer Schwierigkeiten. Unser Ziel war, die Entwicklung des erwachsenen Fettkörpers bei verschiedenen Altersgruppen über das Jahr hinweg qualitativ und quantitativ als Parameter für den physiologischen Zustand und für die Lebenserwartung des Insekts zu untersuchen. 


\section{Material und Methoden}

Es wurde eine Präparierungs- und Einbettungstechnik entwickelt, um die Zellen des segmentalen Fettkörpers an einigen Serienschnitten zu untersuchen. Die Lagen des dorsalen Fettkörpers wurden nach Entfernung der Eingeweide in Wyatt-Lösung sorgfältig aus dem Abdomen herauspräpariert und auf einem Deckglas ausgebreitet.

Nach Fixierung auf dem Deckglas wird das Gewebe für die Paraffin-Einbettung dehydriert. Die Einbettung erfolgt mit Hilfe eigens dafür entwickelter Messinginstrumente (Fig. 1-3) nach den auf Fig. 4 dargestellten Schritten.

Die Verteilung der Oenozyten wurde an 4 und 35 Tage alten Herbstbienen untersucht. Sie wurden in den Arealen 1 bis 7 (Fig. 5) an den Fettkörpern des 3., 4., 5., und 6. Tergits gezähIt. Die relative Dichte der Proteingranula in den Fettzellen wurde durch Zählung der Punkte auf den Negativen von Mikroaufnahmen, projeziert auf ein Raster, gezählt. Die Dichte der Granulat wurde zwischen den verschiedenen Segmenten und innerhalb des 3. Segments verglichen.

\section{Resultate}

Eine allgemeine Beschreibung des dorsalen Fettkörpers und der auf unseren histologischen Schnitten zu findenden Zelltypen wird duch die Fig. 6-9 vermittelt. Die Verteilung der Oenozyten ist bei den Fettkörpern der verschiedenen Tergite nicht dieselbe. Wie auf Fig. 10 zu sehen, besteht immer ein Gradient vom Herzen, wo die Dichte am geringsten ist, zu den seitlichen Anteilen des Fettkörpers. Am 3. Segment ist das Areal rund um das Herz völlig frei von Oenozyten.

Bei 12 Tagen alten Herbstbienen ist die relative Dichte der Proteingranula in den Fettzellen bei allen untersuchten Tergiten dieselbe (Tab. 1), und die Bildung der Granula erfolgt in deil verschiedenen Segmenten synchron. Bei 35 Tage alten Tieren besteht ein signifikanter Einfluß des Untersuchungsareals innerhalb eines Segments auf die relative Granulakonzentration, aber nicht bei 8 Tage alten Bienen (Tab. 2). Offensichtlich erfolgt die Ablagerung der Granula in Arealen, die mit anderen Geweben in Kontakt stehen, schneller.

Die vorliegenden Resultate bilden eine notwendige Vorbedingung für eine genaue Probeentnahme, wie sie für künftige quantitative L.M.- und E.M.-Analysen notwendig ist.

\section{REFERENCES}

Böнм B., 1964. - Beziehungen zwischen Fettkörper, Oenocyten und Wachsdrüsenentwicklung bei Apis mellifica L. Z. Zellforsch., 65, 74-115.

Ganter P., Jolles G., 1969. - Histochimie normale et pathologique I. Gauthier-Villars, Paris.

HAYDAK M.H., 1957. - Changes with age in the appearance of some internal organs of the honeybees. Bee World, 38 (8), 197-207.

Keltey L.I., 1978. - Endocrine regulation of fat body development and function. Amur. Rev. Entomol., 23, 329-352.

KurbY B.A., 1963. - The biochemistry of the insect fat body. Adv. Insect Physiol., 1, 111-174.

Koenler A., 1921. - Beobachtungen über Veränderungen am Fettkörper der Biene. Schweiz. Bienenztg., 44, 424-428. 
Kramer U., 1962. - Histologische Beobachtungen über das Verhalten der Oenocyten im Individualzyklus der Honigbiene und im Jahreszyklus des Bienenstaates. Z. Morph. Okol. Tiere, 51, 63-86.

Lotmar R, 1939. - Der Eiweiss-Stoffwechsel im Bienenvolk (Apis mellifica) wïhrend der Uberwinterung. Landwirtsch. Jahrb. Schweiz, 36-70.

Maurizio A., 1954. - Pollenernährung und Lebensvorgänge bei der Honigbiene (Apis mellifica I.). Landwirtsch. Jahrb. Schweiz, 68, 115-182.

Maurizio A., 1961. - Lebensdauer und Altern bei der Honigbiene (Apis mellifica L.). Gerontologia, 5, 110-128.

Mirz R., Gerig L., Wille H., Leurhold R., 1979, - Das Problem der Kurz- und Langlebigkeit bei der Ein- und Auswinterung im Bienenvolk (Apis mellifica L.) : Eine Verhaltensstudic. Rev. Suisse Zool., 86, Fasc. 3, 663-671.

Pfeiffer-Weed J., 1945. - Effect of the corpora allata on the metabolism of adult femali grasshopper. J. exp. Zool., 99, 183-233.

Rockstein M., 1973. - The physiology of insecta. Vol. 1. Academic Press, New York, London.

Snodgrass R.E., 1956. - Anatomy of the honey bee. Comstock. Publishing Associates Ithaca, New York.

Sokal R.R., Rohlf F.J., 1969. - Biometry. The principles and practice of statistics in biological research. W.H. Freeman and Comp., San Francisco.

Tyseli B., Butterworth F.M., 1977. - Different rate of protein granule formation in the larval fat body of Drosophila melanogaster. J. Insect Physiol., 24, 201-206. 